\title{
Identification of SFPQ as novel interacting partner of HIV-1 Integrase and its functional characterization
}

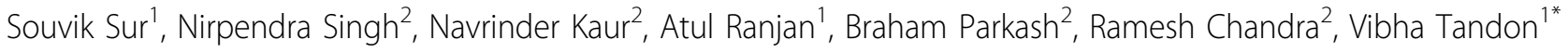 \\ From First International Science Symposium on HIV and Infectious Diseases (HIV SCIENCE 2012) \\ Chennai, India. 20-22 January 2012
}

\section{Background}

HIV-1 requires the support of its appropriate host for the survival and propagation like any other parasite. These host cell factors have been reported to be involved in different stages of viral life cycle. The nuclear import and infection maintenance of HIV-1 Integrase (IN) in human cells is dependent upon the integration efficiency of the proviral DNA and stability of viral RNA. In our study we identified a new host cell interacting factor for HIV-1 IN, SFPQ-a RNA splicing protein, by cross-linking, pull down and mass spectrometry.

\section{Methods}

This study involved gene cloning, protein expression, purification, cell culture, transfection and selection of stable cell lines for the HIV-1 IN GFP fusion protein and in-vitro IN activity assays study.

\section{Results}

We identified a new host cell interacting factor for HIV1 IN-SFPQ, an RNA splicing protein that interacts with HIV-1, shows 5 fold binding $\left(K_{d} 0.05 \mu \mathrm{M}\right)$ and modulates its disintegration activity.

\section{Conclusions}

This study presents SFPQ as a novel cellular factor which has functional interaction with HIV-1 IN. SFPQ, revealed that this protein is not only recruited to the sites where viral genome integration takes place but also increases the disintegration activity and 3' end processing activities of HIV-1 IN.

* Correspondence: vibhadelhi@hotmail.com

1 Department of Chemistry, University of Delhi, India

Full list of author information is available at the end of the article

\section{Author details}

${ }^{1}$ Department of Chemistry, University of Delhi, India. ${ }^{2}$ Dr. B. R. Ambedkar Center for Biomedical Research, University of Delhi, India.

Published: 4 May 2012

doi:10.1186/1471-2334-12-S1-P80

Cite this article as: Sur et al:: Identification of SFPQ as novel interacting partner of HIV-1 Integrase and its functional characterization. BMC Infectious Diseases 2012 12(Suppl 1):P80.
Submit your next manuscript to BioMed Central and take full advantage of:

- Convenient online submission

- Thorough peer review

- No space constraints or color figure charges

- Immediate publication on acceptance

- Inclusion in PubMed, CAS, Scopus and Google Scholar

- Research which is freely available for redistribution

Submit your manuscript at www.biomedcentral.com/submit
C Biomed Central 